Bayero Journal of Pure and Applied Sciences, 4(2): 147 - 149

Received: October, 2011

Accepted: November, 2011

ISSN $2006-6996$

\title{
ACUTE TOXICITY STUDY OF "GADAGI" TEA ON RATS
}

\author{
${ }^{*}$ A. M. Gadanya, M. S. Sule and M. K. Atiku \\ Department of Biochemistry, Bayero University, Kano. \\ *Correspondence author
}

\begin{abstract}
Acute toxicity study was carried out on three most common types of "Gadagi" tea preparations, "sak", "sada" and "magani".. LD 50 values of each type of the tea were determined. Results of phase $I$ and phase II of the study showed no mortality was recorded in any of the experimental groups of rats in 24hours and up to four weeks after oral administration of $5000 \mathrm{mg} / \mathrm{kg}$ of each type of the tea. Hence, oral administration of all the "Gadagi" tea preparations studied at a dose of less than or equal to $5000 \mathrm{mg} / \mathrm{kg}$ (equivalent to $7.90 \mathrm{~cm}^{3}, 6.90 \mathrm{~cm}^{3}$ and $8.20 \mathrm{~cm}^{3}$ for "sak", "sada" and "magani" respectively) could be safe.
\end{abstract}

Keywords: Acute Toxicity, Lethal Dose, "Gadagi" tea.

\section{INTRODUCTION}

Acute toxicity is the ability of a chemical to cause ill effect "relatively soon" after one oral administration or a 4 - hour exposure of a chemical in air (Senin, 2006). "Relatively soon," is usually defined as a period of minutes, hours (24) or days (up to about 2 weeks) but rarely longer (Senin, 2006). LD stands for "Lethal dose." $\mathrm{LD}_{50}$ is the amount of material, given all at once, which causes the death of $50 \%$ of a group of test animals. The $\mathrm{LD}_{50}$ is one way to measure the short - term poisoning potential (acute toxicity) (Senin, 2006).

Toxicologists can use many kinds of animals but most often testing is done with rats and mice. It is usually expressed as the amount of chemical administered (e.g. milligrams) per 100grams (for smaller animals) or per kilogram (for bigger subjects) of the body weight of the test animal. The $L_{50}$ can be found for any route of entry or administration, but dermal and oral administration methods are the most common. The $L_{50}$ value obtained at the end of the experiment is identified as $\mathrm{LD}_{50}$ (oral), $\mathrm{LD}_{50}$ (skin) e.t.c. as appropriate. The most frequently performed lethality study is the oral $L_{50}$. The results of oral studies are important for drugs, food and accidental domestic poisonings. In general, the smaller the $\mathrm{LD}_{50}$ value, the more toxic the chemical is. Also, the larger the $L_{50}$ value, the lower the toxicity (Senin, 2006).

$\mathrm{LD}_{50}$ value can be compared to other values using a toxicity scale. Confusion sometimes occurs because several different toxicity scales are in use. The two most common scales used are the "Hodge and Sterner scale" and the "Gosselin, Smith and Hodge scale (Senin, 2006)." These tables/scales differ in both the numerical rating given to each class and the terms used to describe each class. It is important to know that the actual $\mathrm{LD}_{50}$ value may be different for a given chemical depending on the route of exposure (Oral, dermal, inhalation) (Senin, 2006).
"Gadagi" tea is a composite used as a stimulant mostly by drivers and commercial motorcyclists in Kano and some parts of Northern Nigeria. Many "Gadagi" tea consumers get involved in accidents which the society rightly or wrongly attributed to the negative effect of the tea. There are three major types of "Gadagi" tea, viz:

1."Sak"/baki: This is a mixture of sugar (76g), highland tea $(5.69 \mathrm{~g})$ and mint plant $(0.3 \mathrm{~g})$ boiled together in water (1 liter).

2. "Sada": This is a mixture of sugar $(114 \mathrm{~g})$, highland tea $(5.69 \mathrm{~g})$, ginger $(4.40 \mathrm{~g})$, lemon grass $(0.30 \mathrm{~g})$, mint plant $(0.30 \mathrm{~g})$ and negropepper $(0.34 \mathrm{~g})$ boiled together in water (1 liter).

3. "Magani": This is a mixture of sugar (76g), highland tea $(5.69 \mathrm{~g})$, leaves of Citrus aurantiifollia (3.50g), garlic $(1.00 \mathrm{~g})$, chips of African mahogany $(3.80 \mathrm{~g})$, mango leaves $(2.50 \mathrm{~g})$, Thonningi sanginue $(0.80 \mathrm{~g})$ and leaves of river red gum $(2.50 \mathrm{~g})$ boiled together in water (1 liter).

Other types include, garlic/herbal, ginger, "gahwa", and "shayi da magani". The component of each varies from one individual producer to another. In addition, there are some special types called 'cockroach' and even 'bastard'. The 'cockroach' type is "Gadagi" tea with high concentration of Nescafe. The bastard type has high concentration of "Alabukun" (acetylsalicylic acid). Also, there is another type of "Gadagi" tea which is boiled with a plant called Wiltheria indica, which makes its consumers feel much stronger.

A study has shown that, aqueous extract of African mahogany (khaya senegalenses) and Tea plant (Camellia sinensis), which are among the major ingredients used in preparation of the tea, have hepatotoxic and hyperglycemic effects (Gadanya et al., 2009). Chemical pathology and histopathology test results showed that "Gadagi" tea is hepatotoxic to rats (Atiku et al., 2009). Therefore, this research work is aimed at finding out the $\mathrm{LD}_{50}$ value of the tea, so as to encourage or discourage its consumption. 


\section{MATERIALS AND METHOD}

\section{Sample preparation}

Samples of "sak", "sada" and "magani" types of Gadagi" tea were obtained from Kofar Wambai Market, Kano, Nigeria (one of the oldest and the most popular "Gadagi" tea market). They were subjected to direct heating process. Residues were obtained and weighed using a weighing balance.

The procedure was repeated five times. Average weight was determined and used in the following formular for determination of amounts of tea in $\mathrm{cm}^{3}$ to be administered.

Formula:

Amount of tea $\left(\mathrm{cm}^{3}\right)$
$\frac{\text { Amount consumed by } 70 \mathrm{~kg} \text { man in } \mathrm{cm}^{3} X \text { Average of rats }(g) X \text { dose }(\mathrm{mg} / \mathrm{kg})}{\text { (Gadanya, } 2011)} \quad 100$ Xverage Amount of tea residue $(\mathrm{g})$

Where:

- Amount consumed by $70 \mathrm{~kg}$ man $=700 \mathrm{~cm}^{3}$

- Average amount of tea residue $=53.42 \mathrm{~g}, 60.57 \mathrm{~g}$, and $51.35 \mathrm{~g}$, for "sak", "sada" and "magani" respectively.

- $\quad$ Average weight of rats $=120 \mathrm{~g}$ for "sak" and "magani" groups, and $100 \mathrm{~g}$ for "sada" group.

\section{Determination of Acute toxicity $\left(\mathrm{LD}_{\mathbf{5 0}}\right)$}

The method of Lorke (1983) was used in the $\mathrm{LD}_{50}$ determination.

Three groups of four rats each were orally administered with the tea at doses of $10 \mathrm{mg} / \mathrm{kg}$, $100 \mathrm{mg} / \mathrm{kg}$ and $1000 \mathrm{mg} / \mathrm{kg}$ body weight and were observed for 24hours. In the second phase, four groups of one rat each were administered orally with the tea at doses of $1500 \mathrm{mg} / \mathrm{kg}, 2250 \mathrm{mg} / \mathrm{kg}$, $3500 \mathrm{mg} / \mathrm{kg}$ and $5000 \mathrm{mg} / \mathrm{kg}$. They were observed for 24hours and number of death was recorded. The same procedure was carried out on each of the three types of the tea and $\mathrm{LD}_{50}$ value was determined.

\section{RESULTS AND DISCUSSION}

From the result of acute toxicity study of "sak", "sada" and "magani" (Tables 1a and 1b), no mortality was recorded in any of the experimental groups in 24hours and up to four weeks after oral administration of $5000 \mathrm{mg} / \mathrm{kg}$ of each type of the tea. This is equivalent to $7.90 \mathrm{~cm}^{3} / \mathrm{kg}, 6.90 \mathrm{~cm}^{3} / \mathrm{kg}$ and $8.2 \mathrm{~cm}^{3} / \mathrm{kg}$ for "sak", "sada" and "magani" respectively. For $70 \mathrm{~kg}$ man, this is equivalent to $553 \mathrm{~cm}^{3}, 483 \mathrm{~cm}^{3}$ and $574 \mathrm{~cm}^{3}$ for "sak", "sada" and "magani" respectively. According to toxicity classes of Hodge and Sterner (2005), any compound with oral $\mathrm{LD}_{50}$ (rat) of $5000 \mathrm{mg} / \mathrm{kg}$ or more should be considered as practically harmless. This could be attributed the fact that, all the tea preparations studied contain highland tea which is a product of tea plant (Camellia sinensis). All teas from Camellia tea plant are rich in polyphenols, which are a type of antioxidants (Stephen and Duffy, 2001).A study showed that, "Gadagi" tea contain tannins, saponins, flavanoids, cardiac glycosides and alkaloids (Gadanya, 2011). Diets containing tannins at low dosages $(0.15-0.2 \%)$, have been shown to improve well - being of the human body (Shiavone et al., 2008). Saponins enhance nutrient absorption and aid in animal digestion.Cardiac glycosides could improve circulation and heart function in congestive heart failure (El-olemy et al., 1994).

However, toxicity could occur when teas brewed from plant parts containing cardiac glycosides. Significant toxicity is usually as a result of suicide attempt or inappropriate self-administration for therapeutic purposes (Raffi and Mark, 2009). Also, alkaloids have some pharmacological effects and are used as medications, recreational drugs, or in entheogenic rituals e.g. the local anesthetic and stimulant cocaine, the stimulant caffeine, the analgestic morphine or the antimalarial drug quinine (Tailang and Sharma, 2009). Hence, oral administration of "sak", "sada" and "magani" at a dose of less than or equal to $5000 \mathrm{mg} / \mathrm{kg}$ could be safe.

Table 1: (a-b): Mortality recorded in Lethal Dose $\left(\mathrm{LD}_{50}\right)$ determination for "Sak", "Sada" and "Magani".

(a) Phase I:

\begin{tabular}{cccc}
\hline Dose (mg/kg) & "Sak" & "Sada" & "Magani" \\
\hline 10 & $0 / 4$ & $0 / 4$ & $0 / 4$ \\
100 & $0 / 4$ & $0 / 4$ & $0 / 4$ \\
\multirow{2}{*}{1000} & $0 / 4$ & $0 / 4$ & $0 / 4$
\end{tabular}


(a) Phase II

\begin{tabular}{cccc}
\hline Dose $\mathbf{( m g / k g )}$ & "Sak" & "Sada" & "Magani" \\
\hline 1,500 & $0 / 1$ & $0 / 1$ & $0 / 1$ \\
2,250 & $0 / 1$ & $0 / 1$ & $0 / 1$ \\
3,500 & $0 / 1$ & $0 / 1$ & $0 / 1$ \\
5,000 & $0 / 1$ & $0 / 1$ & $0 / 1$ \\
\hline
\end{tabular}

Key: $(0 / 4) \quad 0=$ number of death, $4=$ number of rats used for test

\section{REFERENCES}

Atiku, M.K., Adamu, D.J.M., Gadanya, A.M. and Shehu, M.A. (2009). The effect of "Gadagi" tea on liver function and serum glucose concentration in Albino rats. Bayero Journal of Pure and Applied Sciences 2 (1):125-127.

El-olemy, M.M., Al-muhtada, F.J., and Afifi, A.A. (1994). Experimental Phytochemistry. A Laboratory Manual. King Saud University Press Riyadh, Saudi Arabia.Pp. 6-65.

Gadanya, A.M., Umar, B. and Atiku, M.K. (2009). Hyperglycemic effect and hepatotoxicity studies of stem bark of Khaya senegalensis and leaf extract of Camellia sinensis. Bayero Journal of Pure and Applied Sciences 2 (1):129-131.

Gadanya, A.M. (2011). Biochemical and Toxicological studies on "Gadagi" tea in rats. Ph.D Thesis. Department of Biochemistry, Bayero University Kano, Pp. 139-142.

Hodge, A. and Sterner, B. (2005) .Toxicity classes. In:Canadian center for occupational Health and safety. Copy right @1997-2010. Retrieved (http://www.ccohs.ca/oshanswers/chemicals/ id50.htm) On 3/5/2010.

Lorke, D. (1983). A new approach to tropical acute toxicity testing. Arch. Toxicol. 53: 275-287.

- Raffi, k. and Mark, S. (2009).Plant poisoning, glycosides-cardiac.Continually Updated Clinical Reference. Retrieved from (http://www.answers.com/topic/glycosides) on $21 / 3 / 2010$.

Senin, R. (2006). Acute toxicity study. Retrieved from (http://www.ccohs.ca/oshanswers/chemicals/ Id50.html) on 27/3/2010.

Shiavone, A., Gup, K. and Tassone, S. (2008). "Effects of a natural extract of chestnut wood on digestibility, performance traits and nitrogen balance of broiler chicks". Poult. Sci. 87 (3): $521-7$.

Stephen, J.and Duffy, M.D.(2001). "Black tea" Retrieved from (htt://en.wikipedia.org/wiki/black-tea) on 12/2/2010.

Tailang, M. and Sharma, A.K. (2009). Phytochemistry (theory and practicals). Birla publications, India.Pp.229-237. 